\title{
Monetary and Fiscal Policy, Tools for Economic Growth. (Test of the Keynesian and Monetarist Preposition): Nigerian Experience
}

\author{
Monogbe Tunde Gabriel*, Davies Nkanbia Llewellyn \\ Faculty of Management Science, Department of Finance and Banking, University of Port Harcourt, Rivers State, Nigeria
}

Email address:

Olatundebusayo19@gmail.com (T. G Monogbe),gbrogbrobo@gmail.com (D. N. Llewellyn)

${ }^{*}$ Corresponding author

\section{To cite this article:}

Monogbe Tunde Gabriel, Davies Nkanbia Llewellyn. Monetary and Fiscal Policy, Tools for Economic Growth. (Test of the Keynesian and Monetarist Preposition): Nigerian Experience. International Journal of Finance and Banking Research. Vol. 2, No. 3, 2016 , pp. 63-71. doi: $10.11648 /$ j.jifbr.20160203.12

Received: March 15, 2016; Accepted: March 30, 2016; Published: May 31, 2016

\begin{abstract}
This paper is set out to investigate monetary and fiscal policy has tools for economic growth in Nigeria and to also investigate which of this tools is most appropriate in the Nigerian present state of economy using time series data spanning from 1981 to 2014. The application of the ECM and granger causality test reveals that total government expenditure (TGE) has a positive and a significant influence in promoting economic growth which canvass support for the Keynesian that increase in government expenditure is a key instrument in promoting economic growth and hence crowd in private investors in Nigeria. While on the other hand, increase in total money supply (TMSS) is negatively significant to economic growth which contradict the opinion of the monetarist. sequel to this, it is however glaring that increase in government expenditure play a lead role in stimulating economic growth in the long run In Nigeria. Based on our finding, we recommend that policy makers should ensure that the large quantum of fund flowing from the government pulse should be apportion asymmetrically to the productive sector of the economy like the manufacturing sector, agricultural sector, and SME's (small and medium enterprises) among others so as to ensure fruitful returns from this investment which will in turn promote economic growth and encourage private investors as earlier stated by the Keynesian school.
\end{abstract}

Keywords: TGE, TMSS, GRANGER CAUSE, RGDP

\section{Introduction}

One begin to wonder the rationale behind the loafs of argument that emanate between the Keynesian school and the monetarist (neoclassical) as to which of the tools is superior or has a greater influence in stimulating economic growth especially when an economy is undergoing serious threat (depression). The Keynesian suggest increased government expenditure while the monetarist insists increase money supply. However, contrary opinion was also fluent by Ricardo who argues that increase in government expenditure nor money supply is irrelevant. He justifies is argument by emphasizing that when government take care of her deficit by reducing tax and increasing borrowing, the tax reduced today will be paid for in double fold in the nearest future. Expansionary fiscal policy occurs when government increase her spending and/or decrease its taxes. Put separately, government spend more in other to meet up are obligations that is, her deficit. It could be on capital expenditure or current expenditures. The ideal of expansionary fiscal policy is introduced by john Maynard Keynes around (1930) who argues that government could amend or change the nature of the economic performance by adjusting tax rate and government spending. Keynes recommended this in the United States when the unemployment rate reaches about $25 \%$ and the level of output drop to about $30 \%$. He argues that expansionary fiscal policy will be used in boosting up the rate of economic performance especially during recession when the nature of the economic growth is in a negative shape. owing to this, he stated that increase in government spending and or reduction in taxes would be a better tools in stimulating economic growth by promoting production, 
reduce the level of unemployment rate, makes little or no different on interest rate and hence promote general economic growth. This ideal generally brought about budget deficit. Expansionary Fiscal policy as a tool for economic performance especially when an economy is faced with persistence high level of unemployment as stated by Keynesian preposition have created various controversy and opinion by different scholars, school of thoughts and writers. According to the classicalist, they believe that government has a little role to play in the economy. The genetic economic condition was assume to be fully employment and that the government should not intervene with the efficient operation in the market. Their however says that economic recession or depression is temporary in nature and that in no time, the economy will return to a level persistent with potential output. However, the neoclassical school are of the opinions that increase in government expenditure crowd out private investors. Their emphasis that increases in government expenditure leads to increase in aggregate demand and bring about high governmental demand for loan able fund. On the same note, this will stimulate high level of competition between the government and the private investors such that interest rate will be sky rocket and finally crowd out private investor has there have little or no access to loan-able fund which is needed for production processes. Mine while, barro's provocative hypotheses is of the opinion that increase in government spending when faced with deficit is irrelevant. The bases of the argument is that government budget deficit do not affect the total demand in the economy as tax cut today will definitely be paid for in the future meaning that the overall demand will remain unchanged. However, this various opinion has put a truck of controversy in the literature as some writer support the neoclassical school, some give in support to the Ricardo school while some canvas support for the Keynesian school. Based on this loafs of argument, the researcher is esteemed to investigate which of the tools is appropriate in the Nigerian economy.

\subsection{Statement to the Problem}

In the Nigerian context, despite the huge amount of government spending in ensuring economic growth, larger percentage of the citizens are still living in gross poverty, unemployment margin is still on the increase, infrastructural facilities are not available, poor road network and educational standard is nothing to write home about. Putting into consideration all of the above, can one emphatically say that the state of economy in Nigeria is experiencing growth or the Keynesian preposition of expansionary fiscal policy is of no effect in the Nigeria context? Sequel to this splitting opinion, the researcher is inspire to test whether or not the Keynesian and monetarist preposition is applicable to the Nigeria system has some scholar has said that no theory seems to work in the Nigeria economy.

\subsection{Study Objectives}

The major objective of this study is to statistically investigate and test the effect of monetary and fiscal policy as tools for economic growth as argue by Keynes and its opponent and its application on the Nigeria economy. The gross objective is stated below

a. To statistically test the effect of total money supply on economic output in Nigeria.

b. To empirically investigate the effect of total government expenditure on economic growth in Nigeria.

c. To draw conclusion and recommendation.

\subsection{Research Questions}

In an attempt to justify the gross objective of this study, we formulate the following research question.

To what extent does total money supply influence economic growth?

To what extent does total government expenditure stimulate economic growth?

\subsection{Research Hypothesis}

In an attempt to actualize the gross objective of this research work, the following hypothesis were formulated in their respective null form.

$\mathrm{H}_{01}$ : There is no significant relationship between total money supply and economic growth in Nigeria.

$\mathrm{H}_{02}$ : total government expenditure does not significantly affect economic growth in Nigeria.

\section{Literature Review}

\subsection{Theoretical Review}

\section{The Monetarist View}

The monetarist argues that only money matters and that increase and decrease in money supply is the major cause of economic expansions and recessions. They however argues that change in money supply will inevitable affect the price level and output in the short run but in the long run, the effect of change in money supply will out rightly affect price level. This is due to the fact that in the long run, the economy is close to full employment. It implies that change in money supply affect national income directly. Obviously, The monetarist outline three effect that will take place on the interest rate if the monetary authority decide to increase money supply and it include liquidity effect, output effect and the price expectation effect.

\subsection{Liquidity, Output and Price Expectation Effect}

The view here is on the notion that increase in money supply will obviously reduce interest rate in the short run hence people will be left with no choice other than to sell their securities and hold more money. Sequel to this, people will spend their excess money on financial asset and consumables which bring about increase in aggregate expenditure. This increase in aggregate expenditure tends to stimulate output level, employment level and income hence bring about output effect which will lead to increase in 
interest rate due to increase in the level of output and demand for money emanating from liquidity effect. Simply put, output effect occurs as a result of increase in aggregate expenditure on financial asset and consumable goods. While price expectation effect occur due to lenders expectation that inflation will continue.

\subsection{Keynesian Preposition}

Keynes argues that when an economy is faced with persistence unemployment, expansionary fiscal policy is a very good tool for economic growth. This preposition however explains that increase in government spending stimulate domestic production, increase savings, increase the level of output in the economy, reduce the level of unemployment, stabilize price and promote the overall economy with little or no influence on interest rate since interest rate sensitivity to investment is very low and hence, private investors is crowd in. Keynes argues that there is a positive nexus between budget deficit and economic growth. He suggests that increased aggregate demand enhances the profitability of private investments and leads to a higher level of investment at any given rate of interest. Keynes emphasis that when an economy is faced with recession, persistence high level of unemployment, and so on, government should solve such problem in the short run and forget about the long run. Keynes is of the opinion that in the long run, we are all dead hence economic problem should be solved in the short run.

\subsection{Neoclassical School}

The neoclassical school has a contrary opinion against the Keynesian preposition of expansionary fiscal policy has an effective tool for economic growth. The neoclassical school argues that increase in government spending stimulate aggregate demand which will result into high government demand for loan-able fund hence lead to competition between private firm and government thereby sky rocket interest rate and crowd out private investors. Hence, there propose inverse relationship between expansionary fiscal policy (budget deficit) and economic growth. The neoclassical specifies that the end point of increase in government spending is to crowd out private investors as the needed fund for investment could not be easily access due to high governmental demand for loan which aggravates interest rate and thereby slowdown growth rate in an economy.

\subsection{Dual Gap Analysis}

This concept outlines three major requirements for an economic to achieve sustainable development. These three requirements are domestic savings, investment and foreign borrowed fund. The theory states that investment is a prominent key in ensuring a substantial growth in an economy. Mine while, the required investment needed for growth might not be attained without domestic saving meaning that investment coupled with domestic saving is a function of economic development according to the theory.
The theory further emphasis that the needed development might not be achieved with only investment and domestic saving hence there is a need to borrow in maintaining a sustainable development. These therefore specified that domestic savings, investment and foreign borrowed fund are appropriate tools for economic development as stated by the theory.

\subsection{Controversies in the Literature}

Series of studies has been carried out both in the Nigerian context and overseas to investigate whether financing deficit through expansionary fiscal policy has explain by Keynes leads to crowd out effect, crowd in effect or is irrelevant as specified in Ricardo hypotheses.

In an attempt to investigate deficit finance, budget deficit and effect of external debt on economic growth, result from findings of the following researchers canvass support for the Keynesian school. Monogbe et al, (2015), suliman et al, (2012), faraji and makame, (2013), tallman and rosensweig, (1991), Eisner, (1991), egwaikhide, (1991), zakiharova et al, (2009), onafowora and owoye, (2006), al-khedir, (1996), osuka and achinihu, (2014) among others. The above reviewed literature are of the opinion that expansionary fiscal policy has a positive nexus to economic growth. On the contrary, in the research work of the following writer, the result of their empirical findings reveals no causality between increase in government expenditure and economic growth thereby canvassing support for the neoclassical school. Ogunmuyiwa, (2011), Ayadi and ayadi (2008), safdari and mehrizi, (2011) examine external debt and economic growth in iran, their findings shows no negative effect canvassing support for the neoclassical. Nwodo, (2001), ben, (2010), obi and abu, (2009), yaya, (2010) and monogbe, (2016).

\subsection{Empirical Review}

To justify that appropriate state of the above reviewed theory in the Nigerian context, we proceed to review the following literature.

Monogbe, (2016) in is paper titled intergenerational effect of external debt on the performance of the Nigeria economy spanning from 1981 to 2014 using granger causality test to determine the causality flow and error correction mechanism to indicate the speed of adjustment from the short run equilibrium to the long run equilibrium state. Findings reveals that increase in money supply promote economic growth suggesting that injection of fund into the economy bring about economic growth thereby canvassing support for the monetarist.

In the research work of ogbulu, et al (2015) titled assessment of the impact of fiscal policy operations on stock price performance; empirical evidence from Nigeria using time series data spanning from 1985 to 2012. Series of estimating tools were used in justify their findings which includes error correction mechanism, granger causality test, variance decomposition and impulse response among others. Findings reveals that government expenditure has a 
significant but negative effect on stock price in Nigeria which suggest an inverse relationship between government expenditure and stock price in Nigeria. On this note, their recommended that appropriate fiscal policy should be enact a profound impact of fiscal policies on stock market price.

In addition, Fatas and Mihov (2001) considered a cholesky ordering in the identification of fiscal shocks. They reported that increase in government expenditure leads to growth in private investment that more than compensates for the fall in private consumption, a feature that goes against the predictions of the Real Business Cycle Model.

Ezirim, et al (2010) reported that public expenditure growth has been seen to significantly and positively precede persistent price increases in Kenya, United Kingdom and the United States of America but not in Nigeria. It was also found that price increases significantly affect public expenditure growth in Kenya and the United States of America.

However, Hsing (2013) conducted a study to examine the potential impacts of fiscal and monetary policies on stock market performance in Poland. The author applied the GARCH model on quarterly data covering the period 1999.Q2 to 2012.Q4. Empirical findings of the study showed that Poland's stock market index is not affected by the ratio of government's deficit or debt to GDP and is negatively influenced by money market rate. The results further demonstrate that Poland's stock market index is positively associated with industrial production and negatively affected by nominal exchange rate and inflation rate respectively.

\section{Research Methodology}

\subsection{Research Design}

This research work is design after ex-post facto method using time series data spanning from 1981 to 2014. Total government expenditure (TGE) and total money supply (TMSS) as a proxy for monetary and fiscal policy while gross domestic product (RGDP) is proxies for economic growth.

\subsection{Source of Data and Operational Measures}

The data used for this research work is a secondary data sourced from the CBN statistical bulletin from 1981 to 2014. In an attempt to justify which of the tool is applicable in Nigeria, we select total money supply (TMS) as monetary policy indicator and (total government expenditure) which is the aggregate of a country's public sector spending in all aspects of government activities as an indicator for fiscal policy while (GDP) is used as an indicator of economic growth.

\subsection{The Model}

Sequel to the above theoretical underpinning and reviewed empiric, we formulated that gross domestic product is a function of monetary and fiscal policy indicator hence, their relationship is model below starting from a functional form.

$$
\mathrm{GDP}_{\mathrm{t}}=\mathrm{f}(\mathrm{TMS}, \mathrm{TGE})
$$

The model is however transform to a mathematical form by introduction of constant thus

$$
\mathrm{GDP}_{\mathrm{t}}=\beta \mathrm{o}+\beta \mathrm{iTMS}_{\mathrm{t}}+\beta 2 \mathrm{TGE}_{\mathrm{t}}
$$

Since mathematical model is too exact and deterministic, we transform the above model into a finametrics form by introducing an error term.

$$
\mathrm{GDP}_{\mathrm{t}}=\beta \mathrm{o}+\beta_{1} \mathrm{TMS}_{\mathrm{t}}+\beta_{2} \mathrm{TGE}_{\mathrm{t}}+\mu \mathrm{i}_{\mathrm{t}}
$$

Where

GDP $=$ gross domestic product

TMS $=$ total money supply

$\mathrm{TGE}=$ total government expenditure

$\beta \mathrm{o}=$ Constant

$\beta_{\mathrm{i}}$ to $\beta_{2}=$ Estimation parameters

On apriori $\beta_{1}>0 \beta_{2}>0$

\begin{tabular}{|c|c|c|c|}
\hline YEARS & RGDP & TMSS & TGE \\
\hline 1981 & 94.33 & 15.3 & 11.41 \\
\hline 1982 & 101.01 & 15.6 & 11.92 \\
\hline 1983 & 110.06 & 16.1 & 9.64 \\
\hline 1984 & 116.27 & 17.3 & 9.93 \\
\hline 1985 & 134.59 & 16.6 & 13.04 \\
\hline 1986 & 134.6 & 17.7 & 16.22 \\
\hline 1987 & 193.13 & 14.3 & 22.02 \\
\hline 1988 & 263.29 & 14.6 & 27.75 \\
\hline 1989 & 382.26 & 12.0 & 41.03 \\
\hline 1990 & 328.61 & 11.2 & 60.27 \\
\hline 1991 & 545.67 & 13.8 & 66.58 \\
\hline 1992 & 875.34 & 12.7 & 92.80 \\
\hline 1993 & $1,089.68$ & 15.2 & 191.23 \\
\hline 1994 & $1,399.70$ & 16.5 & 160.89 \\
\hline 1995 & $2,907.36$ & 9.9 & 248.77 \\
\hline 1996 & $4,032.30$ & 8.6 & 337.22 \\
\hline 1997 & $4,189.25$ & 9.9 & 428.22 \\
\hline 1998 & $3,989.45$ & 12.2 & 487.11 \\
\hline 1999 & $4,679.21$ & 13.4 & 947.69 \\
\hline 2000 & $6,713.57$ & 13.1 & 701.06 \\
\hline 2001 & $6,895.20$ & 18.4 & $1,018.03$ \\
\hline 2002 & $7,795.76$ & 19.3 & $1,018.16$ \\
\hline 2003 & $9,913.52$ & 19.7 & $1,225.97$ \\
\hline 2004 & $11,411.07$ & 18.7 & $1,426.20$ \\
\hline 2005 & $14,610.88$ & 18.1 & $1,822.10$ \\
\hline 2006 & $18,564.59$ & 20.5 & $1,938.00$ \\
\hline 2007 & $20,657.32$ & 24.8 & $2,450.90$ \\
\hline 2008 & $24,296.33$ & 33.0 & $3,240.82$ \\
\hline 2009 & $24,794.24$ & 38.0 & $3,452.99$ \\
\hline 2010 & $33,984.75$ & 20.2 & $4,194.58$ \\
\hline 2011 & $37,409.86$ & 19.3 & $4,712.06$ \\
\hline 2012 & $40,544.10$ & 19.4 & $4,605.39$ \\
\hline 2013 & $42,396.77$ & 18.9 & $5,185.32$ \\
\hline 2014 & $43,843.77$ & 19.9 & $4,578.06$ \\
\hline
\end{tabular}

\section{Data Presentation}

Table 1. The data below is sourced from the CBN statistical bulletin.

SOURCE: CBN statistical bulletin.

We choose to start our empirical analysis with the ordinary lease square estimating tools so as to check the short run relationship between monetary and fiscal policy indicators 
against economic growth and to justify its relative statistic and global utility.

Table 2. Ordinary lease square (OLS).

\begin{tabular}{|c|c|c|c|c|}
\hline \multicolumn{5}{|c|}{ Dependent Variable: RGDP } \\
\hline \multicolumn{5}{|c|}{ Method: Least Squares } \\
\hline \multicolumn{5}{|c|}{ Date: 03/07/16 Time: $12: 20$} \\
\hline \multicolumn{5}{|c|}{ Sample: 19812014} \\
\hline \multicolumn{5}{|c|}{ Included observations: 34} \\
\hline Variable & Coefficient & Std. Error & t-Statistic & Prob. \\
\hline $\mathrm{C}$ & 2236.548 & 852.0868 & 2.624789 & 0.0133 \\
\hline TGE & 8.675267 & 0.191703 & 45.25365 & 0.0000 \\
\hline TMSS & -162.4967 & 54.53667 & -2.979587 & 0.0056 \\
\hline R-squared & 0.989514 & \multicolumn{2}{|c|}{ Mean dependent var } & 10864.64 \\
\hline $\begin{array}{l}\text { Adjusted R- } \\
\text { squared }\end{array}$ & 0.988837 & \multicolumn{2}{|c|}{ S.D. dependent var } & 14100.49 \\
\hline $\begin{array}{l}\text { S.E. of } \\
\text { regression }\end{array}$ & 1489.769 & \multicolumn{2}{|c|}{ Akaike info criterion } & 17.53473 \\
\hline $\begin{array}{l}\text { Sum squared } \\
\text { resid }\end{array}$ & 68801728 & \multicolumn{2}{|c|}{ Schwarz criterion } & 17.66941 \\
\hline Log likelihood & -295.0904 & \multirow{2}{*}{\multicolumn{2}{|c|}{$\begin{array}{l}\text { Hannan-Quinn criter. } \\
\text { Durbin-Watson stat }\end{array}$}} & 17.58066 \\
\hline F-statistic & 1462.638 & & & 1.839935 \\
\hline Prob(F-statistic) & 0.000000 & \multicolumn{2}{|c|}{ Durbin-Watson stat } & \\
\hline
\end{tabular}

Source: author's computation

The result of the ordinary lease square regression test reveals from the relative statistics that, total government expenditure (TGE) has a positive and significant relationship to the growth of the Nigeria economy. This is in line with our apriori expectation. TGE with the probability value of 0.0000 against the 0.05 alpha level suggest that a \% change in the government expenditure will bring about 8.67 unit increase in economic growth in Nigeria thereby canvass support for the Keynesian who argues that increase in government expenditure is a key to economic growth and thus crowd in private investors. Hence, this result is in line with the reviewed Keynesian theory and some empirical study like that of Monogbe et al, (2015), suliman et al, (2012), faraji and makame,(2013) among others. On the other hand, the output of the total money supply as an indicator of monetary policy (TMSS) shows that TMSS is significantly related to economic growth but, negative. This suggest that there is an inverse relationship between change in money supply and economic growth in Nigeria. Simply put, $1 \%$ increase in money supply will bring about 162.49 unit decrease in the economic growth in Nigeria all thing been equal. Though the output of our result is contrary to our apriori expectation but has a theoretical backing as explained by the neoclassical school. Looking at the global statistic, the coefficient of determination has a high predictive ability. The adjusted $\mathrm{R}^{2}$ has a value of $0.98 \%$ suggesting that about $98 \%$ variation in the regressand (explained) variable is captured and explained by the regressor (explanatory) variable leaving $2 \%$ for other variable not captured in the model. The fisher's statistic justifies the overall significances of the model while the value of the Durbin Watson statistic show the presence of autocorrelation. Sequel to this, we proceed to LM serial correlation test to justify the result of the Durbin Watson statistic.

Table 3. Breusch-Godfrey Serial correlation LM Test.

\begin{tabular}{|c|c|c|c|c|}
\hline \multicolumn{5}{|c|}{ Breusch-Godfrey Serial Correlation LM Test: } \\
\hline F-statistic & 0.699175 & \multicolumn{2}{|c|}{ Prob. F $(1,30)$} & 0.4097 \\
\hline Obs*R-squared & 0.774351 & \multicolumn{2}{|c|}{ Prob. Chi-Square(1) } & 0.3789 \\
\hline \multicolumn{5}{|c|}{ Test Equation: } \\
\hline \multicolumn{5}{|c|}{ Dependent Variable: RESID } \\
\hline \multicolumn{5}{|c|}{ Method: Least Squares } \\
\hline \multicolumn{5}{|c|}{ Date: $03 / 07 / 16$ Time: $12: 55$} \\
\hline \multicolumn{5}{|c|}{ Sample: 19812014} \\
\hline \multicolumn{5}{|c|}{ Included observations: 34} \\
\hline \multicolumn{5}{|c|}{ Presample missing value lagged residuals set to zero. } \\
\hline Variable & Coefficient & Std. Error & t-Statistic & Prob. \\
\hline $\mathrm{C}$ & -179.2239 & 882.6710 & -0.203047 & 0.8405 \\
\hline TGE & -0.055725 & 0.203842 & -0.273374 & 0.7864 \\
\hline TMSS & 12.90365 & 56.93450 & 0.226640 & 0.8222 \\
\hline $\operatorname{RESID}(-1)$ & -0.205601 & 0.245886 & -0.836167 & 0.4097 \\
\hline R-squared & 0.022775 & \multicolumn{2}{|c|}{ Mean dependent var } & $8.29 \mathrm{E}-13$ \\
\hline $\begin{array}{l}\text { Adjusted R- } \\
\text { squared }\end{array}$ & -0.074947 & \multicolumn{2}{|c|}{ S.D. dependent var } & 1443.919 \\
\hline $\begin{array}{l}\text { S.E. of } \\
\text { regression }\end{array}$ & 1497.050 & \multicolumn{2}{|c|}{ Akaike info criterion } & 17.57051 \\
\hline $\begin{array}{l}\text { Sum squared } \\
\text { resid }\end{array}$ & 67234766 & \multicolumn{2}{|c|}{ Schwarz criterion } & 17.75008 \\
\hline Log likelihood & -294.6987 & \multirow{2}{*}{\multicolumn{2}{|c|}{$\begin{array}{l}\text { Hannan-Quinn criter. } \\
\text { Durbin-Watson stat }\end{array}$}} & 17.63175 \\
\hline F-statistic & 0.233058 & & & 1.530765 \\
\hline Prob(F-statistic) & 0.872618 & & & \\
\hline
\end{tabular}

Source: Author's computation

Lagrange multiple (LM) test is a diagnostics test use in identifying the present or absence of serial correlation to prevent model from spurious result. The output of the Godfrey serial correlation LM test is discussed thus. From the result above, we observed that the Obs R-square value is 0.37 hence, greater than the probability level of 0.05 which suggest that we accept the null hypothesis meaning that there is absence of serial correlation. This result nullifies the previous result obtain from the Durbin Watson statistic which suggest present of serial correlation in the OLS output. Based on this output, we proceed to test for stationality of our data using Phillip perron unit root test

It is assume that time series data usually have a problem of stationality due to inconsistency of the data. In an attempt to achieve the objective of this research work, we choose to use Phillip perron unit root test in testing for the stationality of our data in other to avoid spurious result.

Table 4. Test for Stationality.

\begin{tabular}{lllll}
\hline Variable & Phillip p stat & Adj t-stat@5\% & prob & order \\
\hline D (RGDP) & -3.83458 & -2.95711 & 0.006 & $1(1)$ \\
D (TGE) & -5.45125 & -2.95711 & 0.001 & $1(1)$ \\
D (TMSS) & -5.89053 & -2.95711 & 0.000 & $1(1)$ \\
\hline
\end{tabular}

Source: author's computation

From the above result, we observe that the entire variable used in the process of research has a unit root but was not stationary at level. This is due to the fact that the observed 
value is greater than its probability value hence we accept null hypothesis. Never the less, the data became stationary at first difference in the order of 1(1) and has no unit root. Sequel to this, we proceed to test for long run association between the variable used in the process of research using Johansson co-integration test.

Table 5. Johansson Co-Integration Test.

\begin{tabular}{|c|c|c|c|c|}
\hline \multicolumn{5}{|c|}{ Date: 03/07/16 Time: $16: 26$} \\
\hline \multicolumn{5}{|c|}{ Sample (adjusted): 19832014} \\
\hline \multicolumn{5}{|c|}{ Included observations: 32 after adjustments } \\
\hline \multicolumn{5}{|c|}{ Trend assumption: Linear deterministic trend } \\
\hline \multicolumn{5}{|c|}{ Series: RGDP TGE TMSS } \\
\hline \multicolumn{5}{|c|}{ Lags interval (in first differences): 1 to 1} \\
\hline \multicolumn{5}{|c|}{ Unrestricted Cointegration Rank Test (Trace) } \\
\hline Hypothesized & & Trace & 0.05 & \\
\hline No. of CE(s) & Eigenvalue & Statistic & Critical Value & Prob.** \\
\hline None * & 0.671658 & 47.71957 & 29.79707 & 0.0002 \\
\hline At most 1 & 0.297195 & 12.08121 & 15.49471 & 0.1531 \\
\hline At most 2 & 0.024556 & 0.795599 & 3.841466 & 0.3724 \\
\hline \multicolumn{5}{|c|}{ Trace test indicates 1 cointegrating eqn(s) at the 0.05 level } \\
\hline \multicolumn{5}{|c|}{ **MacKinnon-Haug-Michelis (1999) p-values } \\
\hline \multicolumn{5}{|c|}{ Unrestricted Cointegration Rank Test (Maximum Eigenvalue) } \\
\hline Hypothesized & & Max-Eigen & 0.05 & \\
\hline No. of $\mathrm{CE}(\mathrm{s})$ & Eigenvalue & Statistic & Critical Value & Prob.** \\
\hline None * & 0.671658 & 35.63836 & 21.13162 & 0.0003 \\
\hline At most 1 & 0.297195 & 11.28561 & 14.26460 & 0.1405 \\
\hline At most 2 & 0.024556 & 0.795599 & 3.841466 & 0.3724 \\
\hline \multicolumn{5}{|c|}{ Max-eigenvalue test indicates 1 cointegrating eqn(s) at the 0.05 level } \\
\hline **MacKinnon & ug-Michelis & 1999) p-values & & \\
\hline
\end{tabular}

From the above table, it is observed that there is a long run nexus between the monetary and fiscal policy tools used in the process of research. This signifies that there is one co integrating equation which implies a long run association between the entire variable used in this research work.

Table 6. Normalized co-integrating coefficients.

\begin{tabular}{lll}
\hline \multicolumn{3}{l}{ Normalized cointegrating coefficients (standard error in parentheses) } \\
RGDP & TGE & TMSS \\
1.000000 & -8.905498 & -267.4764 \\
& $(0.29529)$ & $(69.5454)$ \\
\multicolumn{3}{l}{ Adjustment coefficients (standard error in parentheses) } \\
D(RGDP) & -0.586570 \\
& $(0.11009)$ \\
D(TGE) & -0.033389 \\
& $(0.02025)$ \\
D(TMSS) & 0.001605 \\
& $(0.00024)$ \\
\hline
\end{tabular}

Looking at the normalized co-integration coefficients, both total government expenditure (TGE)-8.9054 and total money supply(TMSS) -267.476 are negative in the short run but became positive and significant in the long run judging by the rule of the $\mathrm{T}$ statistic. which suggest that total money supply and total government expenditure is a good predictor of economic growth in the long run though the TGE tend to be of more significant in the long run compeer to the TMSS.
The outcome of this result is in line with the Keynesian conclusion which suggested that both tools are not competitive but complementary to each other. In this regard, the view of Walter Heller merit consideration holds. On this note, we proceed parsimonious error correction model.

Table 7. Parsimonious error correction model.

\begin{tabular}{|c|c|c|c|c|}
\hline \multicolumn{5}{|c|}{ Dependent Variable: RGDP } \\
\hline \multicolumn{5}{|c|}{ Method: Least Squares } \\
\hline \multicolumn{5}{|c|}{ Date: 03/08/16 Time: $11: 14$} \\
\hline \multicolumn{5}{|c|}{ Sample (adjusted): 19822014} \\
\hline \multicolumn{5}{|c|}{ Included observations: 33 after adjustments } \\
\hline Variable & Coefficient & Std. Error & t-Statistic & Prob. \\
\hline $\mathrm{C}$ & 2050.286 & 898.4902 & 2.281924 & 0.0300 \\
\hline TGE & 8.623750 & 0.208955 & 41.27079 & 0.0000 \\
\hline TMSS & -149.9214 & 57.92065 & -2.588393 & 0.0149 \\
\hline $\mathrm{ECM}(-1)$ & -0.205018 & 0.250010 & -0.820039 & 0.4189 \\
\hline R-squared & 0.989571 & \multicolumn{2}{|c|}{ Mean dependent var } & 11191.02 \\
\hline Adjusted R-squared & 0.988493 & \multicolumn{2}{|c|}{ S.D. dependent var } & 14188.11 \\
\hline S.E. of regression & 1521.992 & \multicolumn{2}{|c|}{ Akaike info criterion } & 17.60664 \\
\hline Sum squared resid & 67177362 & \multicolumn{2}{|c|}{ Schwarz criterion } & 17.78804 \\
\hline Log likelihood & -286.5096 & \multicolumn{2}{|c|}{ Hannan-Quinn criter. } & 17.66767 \\
\hline F-statistic & 917.2754 & \multirow{2}{*}{\multicolumn{2}{|c|}{ Durbin-Watson stat }} & 1.533969 \\
\hline Prob(F-statistic) & 0.000000 & & & \\
\hline
\end{tabular}

Source: author's computation

ECM help in indicating the speed of adjustment from the short run equilibrium state to the long run equilibrium position. From the above result it is very clear that TGE with the probability value of 0.000 against the alpha level of $0.05 \%$ has a positive and significant relationship to economic growth hereby canvassing support for the Keynesian school. While TMSS is significant but negatively related to economic growth. Sequel to this, one can clearly say that TGE is a better tool in stimulating economic growth in the long run. The output of this result has an empirical and theoretical backing of the Keynesian school. Min while, the absolute value of ECM is about $21 \%$ which implies that about $21 \%$ of the disequilibrium in the RGDP is offset by short run adjustment in the explanatory ( predictor) variable yearly.

Table 8. Pair wise granger causality test.

\begin{tabular}{llll}
\hline Pairwise Granger Causality Tests & & & \\
Date: $03 / 07 / 16$ Time: $17: 05$ & & & \\
Sample: 19812014 & & & \\
Lags: 1 & Obs & F-Statistic & Prob. \\
Null Hypothesis: & 33 & 8.77696 & 0.0059 \\
TGE does not Granger Cause RGDP & & 1.34131 & 0.2559 \\
RGDP does not Granger Cause TGE & & 14.1095 & 0.0007 \\
TMSS does not Granger Cause RGDP & 33 & 1.44200 & 0.2392 \\
RGDP does not Granger Cause TMSS & & 6.31576 & 0.0176 \\
TMSS does not Granger Cause TGE & 33 & 1.07560 & 0.3080 \\
TGE does not Granger Cause TMSS & & & \\
\hline utation & & & \\
\hline
\end{tabular}

Source: author's computation

The output of the table presented above is explained thus. The output of the granger causality result is a controversial 
one. From the table above, judging by $0.05 \%$ level of significant, we observe unilateral relationship between total government expenditure (TGE), total money supply (TMS) and the growth of the economy (RGDP) with causality flowing from TGE and TMSS to RGDP. Meaning that TGE and TMSS granger cause RGDP hence we reject null hypothesis. The inception of the result is in line the theoretical underpinning and our apriori expectation.

Table 9. Response of RGDP.

\begin{tabular}{llll}
\hline Period & RGDP & TGE & TMSS \\
\hline 1 & 1293.328 & 0.000000 & 0.000000 \\
& $(161.666)$ & $(0.00000)$ & $(0.00000)$ \\
2 & 870.4550 & 368.3092 & 167.7026 \\
& $(290.295)$ & $(314.878)$ & $(186.912)$ \\
3 & 1055.387 & 745.5500 & 745.3977 \\
& $(343.937)$ & $(409.388)$ & $(260.161)$ \\
4 & 1557.734 & 685.6541 & 1364.050 \\
& $(463.356)$ & $(560.759)$ & $(398.503)$ \\
5 & 1926.006 & 583.8853 & 1783.488 \\
& $(635.936)$ & $(793.037)$ & $(564.834)$ \\
6 & 2188.077 & 393.1930 & 2073.228 \\
& $(772.776)$ & $(1009.96)$ & $(750.575)$ \\
7 & 2362.187 & 266.7122 & 2237.724 \\
& $(880.043)$ & $(1205.44)$ & $(929.371)$ \\
8 & 2496.445 & 148.4166 & 2338.671 \\
& $(966.407)$ & $(1340.57)$ & $(1084.86)$ \\
\hline \multirow{3}{*}{9} & 2597.056 & 98.53147 & 2396.010 \\
& $(1037.73)$ & $(1434.20)$ & $(1201.05)$ \\
10 & 2695.767 & 73.64104 & 2453.149 \\
& $(1095.86)$ & $(1478.81)$ & $(1276.35)$ \\
\hline
\end{tabular}

Source: author's computation

The result of the impulse response estimate is represented to one standard deviation innovation in each of the variables (RGDP), (TGE) and (TMSS) respectively in a period of 10 years into the future. The figure in the parenthesis represents the standard error of the estimation. From the above table, it is observe that the impulse response of RGDP to own shock is positive all through the 10 year. Ranging from the 1 st year, the impulse response of RGDP to own shock is about 1293.3 unit in the $1^{\text {st }}$ year will the impulse response of RGDP to shock emanating from other variable such as TMSS, TGE is 0.0000 in the $1^{\text {st }}$ year. In the $2^{\text {nd }}$ year, we experience a little change as the impulse response to RGDP own shock reduces to 870.45 unit while impulse response to RGDP shock emanating from other variable increase to about 368.31 unit for TGE and 167.7 unit for TMSS respectively. In the $10^{\text {th }}$ year, the impulse response of RGDP to own shock increase to 2695.76 unit while that of shock emanating from other variable are 73.64 and 2453.14 unit respectively suggesting a multi-variance move in the long run.
Table 10. Variance decomposition estimate.

\begin{tabular}{lllll}
\hline \multicolumn{2}{l}{ Variance decomposition of } & \multicolumn{2}{l}{ RGDP } \\
\hline Period & S.E. & RGDP & TGE & TMSS \\
\hline 1 & 1293.328 & 100.0000 & 0.000000 & 0.000000 \\
2 & 1610.641 & 93.68676 & 5.229110 & 1.084132 \\
3 & 2195.329 & 73.53985 & 14.34798 & 12.11216 \\
4 & 3094.634 & 62.34642 & 12.12956 & 25.52402 \\
5 & 4099.757 & 57.59317 & 8.939431 & 33.46740 \\
6 & 5103.779 & 55.54220 & 6.361736 & 38.09607 \\
7 & 6058.633 & 54.61588 & 4.708297 & 40.67582 \\
8 & 6959.216 & 54.26335 & 3.614039 & 42.12261 \\
9 & 7805.508 & 54.20483 & 2.888773 & 42.90640 \\
10 & 8614.898 & 54.28979 & 2.378765 & 43.33145 \\
\hline
\end{tabular}

Source: author's computation

The above table shows the variance decomposition of the three variables used in the process of research for the period of 10 years forecasting into the future. Ogbulu, (2012) however explains that variance decomposition help in identifying the total proportion of forecast error allocated to own shocks and to shock in other variable in a model. From the above result, we observe that variance decomposition of RGDP to own shock in the $1^{\text {st }}$ year is $100 \%$ leaving noting to other variables. In the $2^{\text {nd }}, 3$ rd to the $10^{\text {th }}$ year, the variance decomposition of RGDP to own reduces simultaneously to $54.28 \%$ leaving about $2.37 \%$ and $43.33 \%$ to other explanatory variable respectively.

\section{Summary and Discussion of Findings}

In Synopsis, this paper tend to empirically investigate and justify the argument between the monetarist and the Keynesian school as to which tools is most appropriate in stimulating economic growth. However, series of argument has also emanate from the literature where some scholar canvass support for the Keynesian and others supported the neoclassical and the monetarist. Haven said all that, we present our summary and discussion of our findings thus.

The result of our findings from the OLS shows that total government expenditure (TGE) is positive and significantly related to economic growth with a probability value of 0.000 as against the alpha value of 0.05 level of significant. On this lighter note, the Keynesian argument holds which suggest that increase in government expenditure plays a magnificent role in stimulating economic growth and hence crowd in private investors. This result is also in line with our apriori expectation and also in line the some work in the reviewed literature like that of monogbe, et al (2015), suliman et al, (2012), faraji and makame, (2013). Mine while, the result of the total money supply (TMSS) show a significant but negative relationship to economic growth which implies that $1 \%$ change in the TMSS will lead to about 162.4 unit decrease in the economic growth and vice versa all things been equal. This result negate our apriori expectation and also the monetarist argument but is in line with the neoclassical argument which upheld the fact that increase in total money supply will skyrocket interest rate in the long run 
and hence lead to price expectation effect. Some empirical findings also support the fact that increase in money supply has a negative influence on the growth of the economy like the work of ben, (2010), obi and abu, (2009), yaya, (2010) and monogbe, (2016).

The result of the Lagrange multiple test (LM) is carried out to justifies that fact that our model is free from serial correlation so as to avoid spurious result. Mine while, stationality test was also conducted considering that fact that time series data are assume to have problem of stationality. The entire variable used in the process of research have unit root at level but not stationary. The variables became stationary at $1^{\text {st }}$ differencing in an integrated order of 1(1) using Phillip perron unit root test.

The Johansson co-integration test shows one co-integrating equation judging by $5 \%$ level of significant and a lag interval of 1 to 1 which implies that there is a long run association between the entire variable used in the process of research. On the same vein, many researchers usually avoid the normalized co integrating coefficient when analysing the Johansson co integration test result. But, we did it fit to analysis it and explain the finance in the test thus. It the short run, it was observed that TMSS and TGE have a negative value of -267.47 and -8.905 respectively. But in the long run, the coefficient of their standard error in the parenthesis change and became positive. Judging by the $\mathrm{T}$ statistic $3 \%$ level of significant, the value of the TMSS in the long run becomes 3.846 while that of TGE is 30.158 respectively. On this note, it is clear that increase in the government expenditure (TGE) is a better tools in stimulating economic growth in the long run while TMSS is an appropriate tools for the short run.

The output of the granger causality result is a controversial one. Judging by $0.05 \%$ level of significant, we observe unilateral relationship between total government expenditure (FGE) and the growth of the economy (RGDP) with causality flowing from TGE to RGDP. Meaning that TGE granger cause RGDP hence we reject null hypothesis. The inception of the result is in line the theoretical underpinning and our apriori expectation as suggested by the Keynesian school that increase in government expenditure stimulate economic growth and hence crowd in private investors. This result is in consonant with the empirical finding of Onafowora and Owoye, (2006), al-khedir, (1996), Osuka and Achinihu, (2014). On the other hand, there is also a unilateral relationship between total money supply (TMSS) and economic growth (RGDP) with causality flowing from TMSS to RGDP. This implies that TMSS granger cause RGDP hence, we reject null hypothesis. This result is also in line with the monetarist view suggesting that money matters.

Finally, the output of the impulse response and variance decomposition shows that RGDP to own shock is positive all through the 10years under study.

\section{Conclusion and Recommendations}

This paper is set out to investigate monetary and fiscal policy has tools for economic growth in Nigeria and to also investigate which of them is most appropriate in the Nigerian present state of economy using time series data spanning from 1981 to 2014. The application of the ECM and granger causality test reveals that total government expenditure (TGE) has a positive and a significant influence in promoting economic growth while increase in total money supply (TMSS) is negatively significant to economic growth. Based on our findings, we hereby recommend that policy makers should ensure that the large quantum of fund flowing from the government pulse should be apportion asymmetrically to the productive sector of the economy like the manufacturing sector, agricultural sector, sme's among others so as to ensure fruitful returns from this investment which will in turn promote economic growth and encourage private investors as earlier stated by the Keynesian school.

\section{References}

[1] Al-Khedair, S. I. 1996. The Impact of Budget Deficits on the Key Macroeconomic Variables in Major Industrial Countries. Florida: Florida Atlantic University Press.

[2] Ayadi, F.S and Ayadi, F.O (2008). "The Impact of External Debt on Economic Growth: A Comparative Study of Nigeria and South Africa". Journal of Sustainable Development in Africa. 10 (3).

[3] Ben, O. and Abu, N. 2010. Do fiscal Deficits Raise Interest Rates in Nigeria? A Vector Auto regression Approach. Journal of Applied Quantitative method.

[4] Egwaikhide, F. O. (1999). Effects of Budget Deficit on Trade Balance in Nigeria: A Stimulation Exercise, African Development Review 11(2), 265-289.

[5] Ezirim, C. B., Muohgalu, M. I., Elike, U., \& Amuzie, A. E. (2010). Public expenditure growth, inflation and cointegration: evidence from Nigeria. International Journal of Business and Behavioural Sciences' Research, 1(1), 1-14.

[6] Fatas, A., \& Mihov, I. (2001). The effects of fiscal policy on consumption and employment: theory and evidence, CEPR, Working Paper, No. 2760.

[7] Faraji Kasidi and Makame Said, A. (2013). "Impact of External Debt on Economic Growth: A Case Study of Tanzania". Advances in Management and Applied Economics. 3(4), 59-82.

[8] Hsing, Y. (2013). Effects of fiscal policy and monetary policy on the stock market in Poland. Economies, 1, 19-25. http://dx.doi.org/10.3390/economies 1030019

[9] Ikechukwu S. Nnamdi, (2015) financial market funds and economic growth nexus in Nigeria: a cointergration perspective with lessons. European journal for business and management 7(2), 2015.

[10] Jhingan, M.L. Macro economic theory $12^{\text {th }}$ edition. Vrinda publications (p) ltd, ISBN 978-8281-298-7.

[11] Monogbe, et al (2015). Deficit finance and the Nigeria economic performance. International Journal of Advanced Academic Research | Social Sciences and Education | (1), 3 (December 2015). 
[12] Monogbe, (2016) intergeneration effect of external debt on the performance of the Nigeria economy. Saudi Arabian journal of business and development studies. (5), 2, January 2016.

[13] Nwodo, D. 2000. The Long-run Effect of Budget Deficit on Economic Growth in Nigeria. Oxford University Press.

[14] Ogunmuyiwa, M.S. (2011). "Does External Debt Promote Economic Growth?" Current Research Journal of Economic Theory, 3(1), 29-35.

[15] Ogbulu, O.N., Torbira L.L. \& Umezinwa C.L (2015). Assessment of the Impact of Fiscal Policy Operations on Stock Price.

[16] Performance: Empirical Evidence from Nigeria. International Journal of Financial Research. 6(2), 2015.

[17] Osuka B.O, and Achinihu J.C (2014). The Impact Of Budget Deficits On Macro-Economic Variables In The Nigerian Economy (1981 - 2012), International Journal for Innovation Education and Research www.ijier.net Vol. 2-11, 2014.
[18] Onafowora, O. A., and Owoye, O. (2006). An Empirical Investigation of Budget and Trade Deficits: The Case of Nigeria, The Journal of Developing Areas 39(2), 153-174.

[19] Omoka, P. C. and Oruka, L. I. 2010. Budget Deficits, Money Supply and Inflation in Nigeria. European Journal of Economics, Finance and Administrative Sciences, 19.

[20] Sulaiman, L.A. and Azeez, B.A. (2012). "Effect of External Debt on Economic Growth of Nigeria". Journal of Economic and Sustainable Development, 3(8).

[21] Tallman, W. and Rosensweig (1991). Investigations U.S. Government and Trade Deficits Economic Review (Federal Reserve Bank of Atlanta) 1-11.

[22] Yaya, K. 2010. Budget Deficit and Economic Growth: Causality Evidence and Policy Implications for WAEMU Countries. European Journal of Economic, Finance and Administration Sciences. Issue 18. 